\title{
Project risk management practices: the organizational maturity influence
}

\author{
José Crispim (Escola de Economia e Gestão, Universidade do Minho, Braga, Portugal and INESC TEC, Porto, \\ Portugal), Luiz Henrique Silva (Brazilian Navy, DGePEM, Brasília, Brazil), Nazaré Rego (Escola de Economia e \\ Gestão, Universidade do Minho, Braga, Portugal and INESC TEC, Porto, Portugal)
}

\begin{abstract}
Purpose

- This work identifies patterns of project risk management (PRM) practices' adoption, and provides empirical evidence concerning the importance (and key attributes) of organizational PRM maturity to the use of risk related practices and project performance.

Design/methodology/approach

- The research involved two phases: interviews with five project managers, and a worldwide survey of project managers that resulted in the analysis of 865 valid questionnaire responses. Cluster Analysis was used to classify PRM practices' use, Factor Analysis to detect the structure of the relationship between the variables measuring PRM practices' use and a Multiple Regression Analysis (with Canonical Correlation) to further reveal the different degrees to which PRM practices and organizational maturity are associated.

Findings

- The identified patterns of risk practices' adoption indicate that different contexts of organization PRM maturity and project complexity influence practices selection. The PRM practices related with targets (e.g., time-phased budget plan) are the most used, and those related to tools and techniques (e.g., S-curve) are the least used. Additionally, the obtained results confirm that: a) organizational PRM maturity influences risk practices' usage, b) moderated by project complexity, and c) organizational PRM maturity influences project performance.

Originality/value

- Empirical methods were used to investigate the relationship between organizational PRM maturity and a large set of PRM practices with project complexity as a moderator. Gaps in the use of PRM practices (i.e., areas where more PRM knowledge and training are needed) were identified. Finally, this work identifies the attributes of organizational maturity with implications in practices' usage and project performance.
\end{abstract}

Keywords: Project risk management practices; Project risk management maturity; Project complexity; Project performance

\section{Introduction}

Project risk management (PRM) is the systematic process of identifying, analyzing and responding to risks (i.e., project-related events, or managerial behaviors, that are not definitely known in advance, but that have the potential for adverse consequences on a project objective) (PMI, 2004).

Papke-Shields et al. (2010) observed that the use of risk related project 
management (PM) practices is relatively low. Kutsch and Hall (2009) argue that few studies reveal what is actually done by project managers in terms of risk management. Studies in PM show that risk practices are less frequently used in comparison with practices related to time, human resources and cost (Papke-Shields et al., 2010, Zwikael and Ahn, 2011). According to Carbone and Tippett (2004), the inability to cope with risk is one of the main causes for exceeding the budget, deadlines and other objectives. Management of risk is one of the most important processes of PM, a crucial determinant of success (Backlund et al., 2014). As the complexity of projects increases, it becomes more important to assess and control risk throughout all the phases of a project (Cagliano et al., 2015). More evidence to persuade project managers to invest in risk management is needed (Olechowski et al., 2016). This paper identifies patterns in the use of risk practices and studies the dimensions of organization PRM maturity that may influence their adoption, clarifying why certain risk practices are less used and providing insights on how to overcome adoption difficulties.

The choice of the practices depends on the risk management phase (Hillson, 2003) and also on the context of the project (Besner and Hobbs, 2013, Cagliano et al., 2015). In this research, context variables measuring project complexity and the risk management maturity of the company developing the project are used to identify the specificities of practice adoption for each PRM phase. Research addressing the adoption of PM practices has included a limited number of practices: for example, Golini et al. (2015) considered sixteen PM practices, and Vicente-Oliva et al. (2015) considered twelve. In order to assess whether a broad portfolio of practices is known and used by project managers, we adopted a wider view and considered an extensive list of fifty-three PRM practices organized according to the phases of the PRM process.

Cluster Analysis is used to identify patterns of practices' usage. This pattern 
recognition is followed by a context analysis with the aim of finding out in which circumstances given practices are used, i.e., understanding how practice adoption choices may be related to one another and to a given context in terms of project complexity and organizational PRM maturity. Therefore, with this empirical study, we analyze how groups of professionals use risk management practices in different contexts, thus contributing to the scarce literature related to risk management practices. Our first research question is:

RQ1: What are the patterns of PRM practices' usage in different contexts of project complexity and organizational PRM maturity for each phase of the risk management process?

According to Ibbs et al. (2004), PM maturity is the sophistication level of the current PM practices and processes of an organization. Andersen and Jessen (2003) consider that a PM mature organization is in a perfect condition to achieve its objectives and, therefore, it is perfectly conditioned to deal with its projects. Nevertheless, there are no fully matured organizations in the real world, therefore, it makes sense to try to measure or characterize the degree of maturity of an organization (Andersen and Jessen, 2003). Several PM maturity models have been developed to describe and measure PM competence: for example, the Project Management Maturity Model (PMMM) (Kerzner, 2001), the Project Management Process Maturity Model ((PM)²) (Kwak and Ibbs, 2002), the Capability Maturity Model ${ }^{\circledR}$ Integration (CMMI $\left.{ }^{\circledR}\right)$ (SEI, 2006), the Organizational Project Management Maturity Model (OPM3®) (PMI, 2008) or the Risk Management Capability Maturity Model (RM-CM) (Yeo and Ren, 2009). This last model is risk specific and all the other include a part concerning risk management. Maturity models assume that organizational knowledge and experience can be 
translated into procedures (Gareis and Huemann, 2000). The idea that tightly defined, repeatable and predictable processes can directly contribute to the efficiency of organizational systems increased the use of formal PM practices (Pasian, Sankaran, and Boydell 2012). According to the authors, this resulted in a view of PM maturity based on process control. However, the management of undefined projects, where the predictability of processes cannot be reasonably expected, creates new challenges to the organizations. In this situation, as emphasized by Pasian et al. (2012), PM maturity should be defined and assessed using a multi-dimensional approach that includes adaptable variables, such as attitudes or leadership.

Several works have followed the standards to demonstrate PM maturity. For example, Golini et al. (2015) measured organizational maturity in a PM context through the level of PM practices' adoption. Unlike these authors, we consider that organizational PRM maturity is the existence of a PRM orientation (an attitudinal construct) that may be a precondition to PRM practices' use. We adopt the broader view of maturity of Andersen and Jessen (2003) that consider that maturity is best explained as the sum of action (ability to act and decide), attitude (willingness to be involved), and knowledge (an understanding of the impact of attitude and action). Given this link between the two constructs (practices and maturity), it is not our purpose to identify the variables of an organization that can affect its maturity, but rather to analyze the relationship between organizational PRM maturity (described by a set of organizational-specific factors taken from the literature) and the use of PRM practices. More specifically, we investigate whether organizational maturity influences the range of practices used or the frequency of their use, and if this relation can be moderated by context variables such as the project complexity. Our second research question is:

RQ2: Which attributes of organizational PRM maturity contribute the most to 
the use of PRM practices?

In the literature about the relationship between maturity models and project performance, there is no consensus regarding maturity models' contribution to better project performance (Ibbs and Kwak, 2000, Mullaly, 2006, Yazici, 2009).

Looking at the literature that addresses organizational maturity as a broader concept (i.e., considering each of the items that compose maturity more generally, and not a checklist analysis like classical maturity models do), there is also a debate around the relationship between organizational maturity and performance (Thomas and Mullaly 2007). Besner and Hobbs (2013) empirically analyze a large sample of data and conclude that apparently (since the percentage of the variance of the performance explained was low) there is a cause-effect relation between organizational maturity and performance. Torres (2014), based on a literature review, concluded that a higher level of maturity leads to better performance. Brookes et al. (2014) point out the lack of empirical evidence regarding the relationship between PM maturity and project performance. Therefore, another contribution of this study is to add empirical evidence concerning this relationship from a PRM perspective. Our third research question is:

RQ3: Which attributes of organizational PRM maturity contribute the most to project performance?

To address the research questions, we performed five exploratory interviews with project managers in order to compare the PRM practices mentioned in the literature with those known and used by PM professionals, and surveyed professionals in the field of PM worldwide, through the PMI network, to collect information about their risk management experience in the context of the project they had been involved 
in that they consider more relevant (i.e., a significant PRM experience). The survey data was analyzed using multivariate statistics techniques.

\section{Literature review}

This work involved two different types of literature review, one to acknowledge the state-of-the-art around the research topic addressed and to identify related gaps (presented in the next subsection), and a systematic literature review (described in subsection 2.2) to determine how the constructs used in the empirical study have been measured. This systematic literature review was carried out by searching referential databases (namely, EBESCO, Scopus, and Google Scholar) from 1995 onwards, using combinations of appropriate search words: "risk management" or "risk assessment", "practice" or "technique", and "project management". As a result, 96 articles with examples of practices for PRM were identified. Only 29 of these contained practices for all the phases of the risk management process.

\subsection{State-of-the-art}

The development of the field of PM justifies research that focuses on the specificity of PRM practices' use taking the steps of the PRM process into account.

Within the PM literature, the vast majority of the research focuses on assessing the impact of practice adoption on performance (e.g., Golini et al., 2015) or the type of practices adopted considering project complexity (e.g., Badewi, 2016) and study small and context specific groups of practices (e.g., Zwikael and Ahn, 2011, Papke-Shields et al., 2010). There have been few studies examining differences in PM practice depending on contexts variables like organization maturity, industry or project type, project complexity, etc. (Besner and Hobbs, 2013). In the PRM research area, literature is even more scarce (e.g., Cagliano et al., 2015). Differences were observed in PM 
practices' use depending on context variables like project complexity (Papke-Shields et al., 2010) or organization maturity (Besner and Hobbs, 2013), and formal PM practices are indeed being applied in practice, but they are not being applied equally or consistently across all the knowledge areas (Besner and Hobbs, 2013). Some practices are extensively adopted (those associated with time, scope, cost control, and information reports), whereas others are almost neglected (those associated with communication, quality, risk analysis and techniques like earned value management) (Papke-Shields et al., 2010, Zwikael and Ahn, 2011, Golini et al., 2015). Therefore, in this work, we use an international survey to study the diffusion of PRM tools and methodologies among project managers to address these gaps, i.e., this research analyses the use of practices considering: the existence of context variables (e.g., project complexity), and the use of control variables (is the use of PRM practices different depending on the region or on the gender of the project manager?).

This work also studies the PRM maturity of the organization. Maturity models are designed to provide a framework to organizations so that they develop their PM capabilities with two main purposes: identifying the current maturity level and setting directions for further improvements (Crawford 2006), and benchmarking their maturity relatively to others (Grant and Pennypacker 2006). Generally, maturity models are viewed as checkup tools to measure progress and to identify the next steps forward based on explicit PM knowledge areas, without taking into consideration intangible assets (Jugdev and Thomas 2002) that are not easily measurable, but can contribute to a mature PM capability, as, for example, the project context (client or stakeholder's involvement) or tacit human factors (Pasian, Sankaran, and Boydell 2012). While focusing on work progress and ignoring human resource or organizational aspects, these complex frameworks are inflexible. Managing change caused by new technology 
or clients unexpected requirements demands a flexible perspective concerning organizational PM capabilities.

Our position is to look at maturity and measure it, not through verifying if a set of practices is or not followed by the organization, but by checking if there is organization awareness, ability to act and decide, attitude and also knowledge about the management of projects. In this sense, it is important to know if organizations that are considered mature according to this definition apply a wide range of PRM practices or if they apply PRM more frequently than less mature organizations in their day to day activities. Additionally, it is important to perceive the organizational determinants of PM efficacy and if the use of practices is associated with better performance.

In order to narrow the identified gaps, this research aims at determining if organizational maturity influences the set of practices available, if there is a relation between organizational PRM maturity and practices' use moderated by the project complexity, and if higher maturity contributes to a better project performance.

\subsection{Measurement of organizational PRM maturity, project complexity, PRM}

\section{practices' usage, and project performance}

\section{Organizational PRM maturity}

Organizations with a low level of maturity are characterized by management improvisation, lack of knowledge about project steps requirements, unfamiliarity with the standards and inability to establish the required connections between the various knowledge areas. This study focuses on the PRM maturity of organizations. Hillson (1997) proposed a risk maturity model framework inspired in the CMMI (SEI, 2006) and measured PRM maturity in terms of four attributes (culture, process, experience, and application). Yeo and Ren (2009) used organizational culture and learning, stakeholder coalition, leadership, organizational structure and support, technology, risk 
management and PM. Zou et al. (2010) used management (people and leadership) capability in relation to risk, organizational risk culture, ability to identify risks, ability to analyze risks, and development and application of a standardized risk management process. Jia et al. (2013) considered organization structure, management of stakeholders, a program of risk management, risk management culture support, risk management planning, risk identification, risk evaluation, risk response, risk monitoring, and risk report. We measure the existence of a PRM orientation (an attitudinal construct) that may be a precondition to PRM practices' use considering six variables: a) assimilation of the risk management concept, b) awareness of the importance of PRM, c) risk management capabilities, d) attitude towards risk, e) leadership, and f) PM knowledge.

\section{Project complexity}

In the literature, context variables are measured according to different perspectives and using different criteria. Vidal and Marle (2008) defined the complexity of a project as a property of the system that makes it difficult to understand. There have been numerous theoretical discussions about the definition of project complexity and the criteria used to measure it (e.g., Geraldi et al., 2011, Ramasesh and Browning, 2014). However, there is still no consensus around the theme (e.g., Qureshi and Kang, 2015). We collected data about the most common different types of complexity: technological complexity (Lu et al., 2015, Kardes et al., 2013): degree of knowledge about the technology needed; organizational complexity: size of the project team (Vidal and Marle, 2008), number and type of contracts that the project involves (Senescu et al., 2012), and degree of cultural changes imposed by the project (Senescu et al., 2012); environmental complexity (Bosch-Rekveldt et al., 2011): degree of stakeholders' influence on the project, and level of dependence on external organizations; and product 
complexity (Baccarini, 1996): budget, and duration of the project.

\section{PRM practices' usage}

PM practices provide guidance concerning the development of projects in order to ensure better management of resources, within the most common constraints (i.e., time, cost, and quality). The growing adoption of PM (and thus, PRM) practices across a large number of organizations (Winter et al., 2006), generally associated with published models, such as the Capability Maturity Model® Integration (CMMI®) or the Project Management Body of Knowledge (PMBOK $\left.{ }^{\circledR}\right)$, highly influences the success or failure of projects (Papke-Shields et al., 2010). The Guide to PMBOK, by the Project Management Institute (PMI), most recently edited in 2017 (PMI, 2017), is much probably the most well-known PM "best practices" reference. PMBOK standards have been disseminated worldwide, which is an evidence of the increasing acceptance of formal PM methods (Papke-Shields et al., 2010). Although there is some agreement that PM practices may positively influence project success, there is still no consensus on how to choose the most effective and efficient practices (Golini et al., 2015, VicenteOliva et al., 2015, Badewi, 2016). According to Hillson (2003), every phase of a risk management process implies a different level of information and detail, thus requiring specific techniques. We composed an initial list of items, derived from the PRM process (risk identification, risks analysis and evaluation, plan and act against risks, and risks control) captured in the PMBOK Guide (PMI, 2013). This list was extended to incorporate two categories: "management support tasks" and "communication and inclusion practices" that encompass all PRM steps and were identified in the literature (see Table 1 that presents the final list of PRM practices considered in this study and a collection of literature sources mentioning them). Additionally, there were some 
practices added as a result of the information obtained from the interviews with project managers (signaled in Table 1).

Table 1. PRM practices considered in the questionnaire

\section{Project performance}

Project performance evolved from the cost-time-quality triangle to include dimensions such as stakeholders (Lester, 1998), financial criteria (Archer and Ghasemzadeh, 1999), customer satisfaction (Shenhar et al., 2001), project environment (Raz et al., 2002), human resources management (Popaitoon and Siengthai, 2014), behavioral aspects (e.g., communication with clients) (Jugdev and Müller, 2005), crosscultural perceptions (Pinto, 2014), or sustainability (Carvalho and Rabechini Junior, 2015). The performance of a project can be assessed by the number of project objectives that have been satisfied (Papke-Shields et al., 2010) or by a set of criteria that measure project success. It is impossible to find a universal set of criteria to measure project performance since projects differ in size, uniqueness, and complexity (Westerveld, 2003). Success, as a subjective term, depends on the perspective of those measuring it (Jha and Iyer, 2006). The base criteria to evaluate the performance of a project are meeting the budget, the time, and the quality requirements (Fortune et al., 2011), but other can be added. Following the literature, we measured project performance considering the traditional cost targets, time targets, and quality standards triangle plus two common criteria: technical specifications achievement, and customer satisfaction.

\section{Research methods}

Our empirical work was structured around a systematic literature review, discussed 
in the previous section, five exploratory interviews with PM practitioners, and an online self-administered survey. The main objectives of the interviews were to understand if PM practitioners are aware of PRM and identify the PRM practices that they adopt. The interviewees were selected theoretically: they are Brazilian experienced PM practitioners, three of them are currently involved in public-private partnership projects and the other two are risk analysis specialists. The interviews were carried out during September 2014 and were audio recorded and transcribed. Then, a conventional content analysis of the interview transcripts was performed (see Hsieh and Shannon, 2005). The interviewees were questioned about the PRM practices they knew or applied during the project life cycle (the practices the interviewees referred are signaled in the list presented in Table 1). Two of them $(5 \mathrm{~W} 2 \mathrm{H}$, and Balanced Scorecard) were added to the list used in the questionnaires. Observing that list, we can also see that numerous practices were unknown to the project managers interviewed (or, at least, were not used by them regularly).

The questionnaire of the online survey was developed after the literature review and the exploratory interviews and is based on the matrix proposed by del Caño and de la Cruz (2002) that relates project complexity and team maturity to identify best practices in the construction economic sector. At the beginning of the questionnaire, the respondents are asked to answer the questions in relation to the most relevant project they have been involved in. Later, we realized that this became a limitation of the study, since the respondents used as a reference the most complex project and/or that with a better performance.

The questionnaire is organized in five sections: the first, has the aim of collecting background information about the respondent (e.g., function, experience in PM or academic qualifications); the second, is focused on the complexity of the underlying 
project (questions were answered using a 5-point Likert scale); the third, addresses the performance of the project (questions answered using a 5-point Likert scale); the fourth, is dedicated to organizational PRM maturity (questions answered using a 5-point Likert scale); and the fifth, asks the respondents about the level of use of each PRM practice in each PRM process phase during the project execution (using a 4-point Likert scale, because we wanted to avoid neutral answers when questions about actions were involved) and if they know the practice. A pretest of the questionnaire with five PM experts was conducted. Based on their feedback through individual online interviews, slight language corrections were made.

The online survey was administered to PM practitioners from different countries and industries using the PMI network and, subsequently, the snowball method. According to Maxwell (2008), purposive sampling is a type of sampling in which particular settings, persons or events are deliberately selected on behalf of the important information they can provide that cannot be obtained from other sources. Despite the little control over the sampling process, the snowball method is suitable for reaching populations that are difficult to assess, in our case, worldwide dispersed (Bryman and Bell, 2015). Around six thousand email contacts were made, and a total of 1112 questionnaires were returned. After screening, some were excluded because the respondents did not belong to a PM team, resulting in a sample of 865 responses (a response rate of $14,4 \%$ ). This is good for a survey of this type. For example, Ling et al. (2009) obtained a response rate of $17 \%$.

The sample includes respondents from 79 countries from the five continents: $62.2 \%$ of the respondents from 18 American countries; $17 \%$ of the respondents from 24 European countries; $16 \%$ of the respondents from 26 Asian countries; $3 \%$ of the respondents from 9 African countries, and $2 \%$ of the respondents from 2 Oceanian 
countries. The countries with more respondents were the United States $(34.7 \%$ of the respondents), Brazil (10.5\%), Canada (8.3\%), India (4.0\%), and Italy and Spain (2.4\%, each). In table 2, we present the profile of the interviewees and survey respondents.

Most respondents obtained their PRM experience in the following industries: IT $(17.9 \%$ of the respondents), telecommunications $(7.3 \%)$, industrial $(7.2 \%)$, management $(6.9 \%)$, civil construction $(6.8 \%)$, finance $(6.2 \%)$, defense $(5.5 \%)$, public administration (4.7\%), and oil (4.6\%). Twenty-nine different industries were referred. The reasons for the choice of the PRM experience the respondents chose to answer the questionnaire about (the most relevant project they had been involved in) were the team and project dimension ( $15.1 \%$ of the responses), the project budget $(14.9 \%)$, the integration efforts $(13.9 \%)$, the duration of the project $(13.6 \%)$, the influence of the stakeholders $(13.2 \%)$, the technology involved $(12.0 \%)$, the project performance (8.9\%), and the knowledge obtained in terms of new standards $(8.4 \%)$.

Table 2. Profile of the respondents

To assess the internal consistency amongst the responses, we used the Cronbach's alpha (Table 3). The threshold of the Cronbach's alpha should be at least 0.70 (Hair et al., 2014).

Table 3. Cronbach's alpha

Since we define and measure constructs (PRM practices' use, organizational PRM maturity, project complexity, and project performance), there is the need to assess their discriminant/convergent validity. Given the considerable number of items (a total 
of 69), an exploratory factor analysis was used to reduce data, determining the minimum number of factors needed to account for the maximum portion of total variance present in the original data set of variables (Hair et al., 2014). The principal components extraction method with Varimax (variance maximizing) rotation was applied. Both Kaiser-Meyer-Olkin (KMO) test and Bartlett's test of sphericity indicate that the data is suitable for a structural detection. All the items have significant loadings for some factor, therefore, none has been excluded. The factor loads of the variables that constitute each factor are show in Table 6 and Table 7. The factors extracted from the use of PRM practices were labeled to reflect the items that define them. In respect to the other constructs, only one factor per construct (comprising all related variables) was extracted, explaining $61 \%$ of total variance for project complexity, $57 \%$ for project performance, and $62 \%$ for organizational PRM maturity.

Discriminant validity ensures that factors theoretically non-overlapping do in fact not overlap, while convergent validity tests whether factors that should be related are in fact related. To assess the discriminant/convergent validity of the constructs, corrected inter-factor correlations were analyzed (Table 4). Discriminant validity is acceptable if all inter-factor correlations are above 0.30 (Field, 2009), to assure convergent validity correlations below 0.50 should be avoided (Carlson and Herdman, 2010).

Table 4. Pearson inter-factor correlation coefficients

We observed convergent validity between factors of PRM practices' use along the phases of the risk management process, and between the organizational PRM maturity factor and factors of PRM practices' use (mainly, use of planning, 
communication, support, and control practices (coefficients around 0.6)). There is discriminant validity between the project complexity factor and the organizational PRM maturity, all factors of PRM practices' use and the factor of project performance. There is also discriminant validity between the project performance factor and all the factors of PRM practices' use. The moderated relationships identified do not detract the necessary difference that must exist between the factors.

Post-hoc multiple mean comparison tests using Tamhane's T2 tests were performed to test if there are differences in the average level of practices' usage of major regions (Europe, North America, South America, Africa, Asia, Oceania and the Middle East). Relatively to some practices (mainly in the identification, control, and communication steps of the PRM process, and in some specific techniques like the "Scurve" or "CPM, CPA, PERT"), the results obtained led to the rejection of the null hypotheses that the averages of those practices' use are the same in all the regions. Consequently, we use the region as a control variable in subsequent analyses. We used Mann-Whitney's U test to compare the use of PRM practices between genders and could not reject the null hypotheses that the two samples were selected from populations with similar distributions (except for 3 techniques: "5W2H", "S-curve", and "CPM, CPA, PERT"), therefore, we do not use gender as a control variable.

After, the following statistical methods were used to answer the research questions:

a) Cluster analysis (on original variables) was used to identify patterns of PRM practices' usage, answering $R Q 1$. To facilitate the interpretation, the previously determined factor labels are used to explain the clusters identified in the data;

b) To further reveal the different degrees of association between PRM practices' use and organizational maturity, a Multiple Regression Analysis (with 
Canonical Correlation) based on the factors extracted for the PRM practices' use construct was applied.

Cluster Analysis (see, e.g., Hair et al., 2014) has been used in PM (e.g., Golini et al., 2015, Besner and Hobbs, 2013). A two-stage analysis was performed to determine the clusters: a hierarchical method was used to determine the number of clusters, and then a non-hierarchical method was used to allocate the sample cases to a particular cluster, as recommended by experts (e.g., Milligan, 1980, Ketchen and Shook, 1996, Hair et al., 2014). The hierarchical clustering method used was Ward's (1963) minimum variance agglomerative method. Accordingly, the dissimilarity measure used was the squared Euclidean distance (see e.g., Hair et al., 2014). To decide the number of clusters to form, we analyzed the SPSS agglomeration schedule and observed the hierarchical tree diagram (dendrogram). As a result, we decided to partition the PRM experiences into three clusters. To define them, we used a nonhierarchical method, K-means, that has the advantage of optimizing the within-cluster homogeneity and between-cluster heterogeneity (Ketchen and Shook, 1996).

Two assumptions should be taken into account when Cluster Analysis is used: sample representativeness and multicollinearity (Hair et al., 2014). Sample representativeness was assured by the sample size and the range of geographic distributions, ages, educational backgrounds, years and field of experience, and project areas of the respondents. To protect against multicollinearity, we assured that the Tolerance value of all clustering variables is higher or equal to 0.8 . Data representation is good if the clusters are compact and isolated (Jain, 2010).

To test if there are significant differences between the averages of the identified groups (clusters), we performed post-hoc multiple mean comparison tests using Tamhane's T2. The averages of all groups are statistically different for all the practices. 
The classification accuracy of the clustering process was evaluated using a simultaneous estimation Discriminant Analysis (see, e.g., Hair et al., 2014), resulting in $91 \%$ of the cases (i.e., PRM experiences) being correctly classified using the discriminant functions that were determined from the classification of the cases according to the a priori assignment to a cluster (as a consequence of the clustering process described). The function that discriminates more is strongly positively correlated with control and planning practices.

All constructs under analysis are composed by several variables. This is a limitation for the use of most multivariate techniques. The Canonical Correlation Analysis (CCA) overcomes this limitation. A CCA quantifies the correlation between two canonical (latent) variables: one representing a set of independent variables, and another a set of dependent variables. The canonical correlation is optimized such that the linear correlation between the two latent variables is maximized (Hair et al., 2014). We used the Canonical Square Correlation (RC2) and the Hotellings test (p-value < 0.05) to assess the goodness-of-fit of the model. The CCA derives as many functions as the minimum number of variables contained in the independent/dependent set.

\section{Results and discussion}

\subsection{Patterns in the usage of PRM practices (RQ1)}

To answer the first research question, we partitioned the cases, in terms of practices' usage, into a small number of homogeneous groups (clusters) different from one another. The Cluster Analysis performed resulted in the identification of three groups (clusters) of PRM practitioners' experiences. We can observe (Table 5) that PRM practices' use is clearly higher in cluster A (33\% of the cases), average level in

cluster B ( $48 \%$ of the cases) and lower in cluster C (19\% of the cases). The set of PRM practices less used is related with tools and techniques, an area for improvements. On 
the contrary, communication and control practices (mostly related to time and cost control) are the most used. The PRM practices used more frequently are: in the identification phase, "risk register, documentation form or management ledger", "project time schedule", "time-phased budget plan monitoring", and "periodic risk review" (of the information record and targets factors); in the evaluation phase, "risk register, documentation form or management ledger", "RBS" and "probability and impact grids, risk matrix, risk map" (of the analysis of records factor); in the planning phase, "action plan, mitigation plan", "contingency plan"; in the monitoring phase, all the practices of the control by goals factor; in the communication phase, "communication practices"; and in the support phase, "periodic project meeting" and “document review".

The less used PRM practices are: in the identification phase, all the practices of the tools and techniques factor; in the evaluation phase, the practices of the tools and techniques factor with the exception of "CPM analysis"; in the planning phase, "design flexibility"; in the monitoring phase, the practices of the tools and techniques factor with the exception of "customer satisfaction survey" and "KPIs library"; in the communication phase, "integration practices" for clusters A and C; and in the support phase, "TQM, ISO standards, EFQM", "project risk management maturity analysis", and "prototype or mock-up".

It seems that relatively simple PRM practices (e.g., control by goals or cost/time targets) are more adopted by project managers, while more complex tools, that require the acquisition of new expertise, are less used. This is in line with the results of Fortune et al. (2011) and Fortune and White (2006).

Another important information is the percentage of respondents that do not know a certain practice (see Table 5), clearly higher in cluster C (e.g., HAZAN, HAZOP with 
42.1\% or FMEA $35.9 \%$ ). Even in cluster A, these techniques are unknown for a considerable percentage of cases $(8.6 \%$ and $4.1 \%$, respectively). This situation is not specially related with a specific phase or area of knowledge (like statistics or decision analysis), but instead with the use of tools and techniques in general. For example, even the "CPM, CPA, PERT" set of techniques of the PM field has considerable percentages of unawareness (around 10\%, in cluster $\mathrm{C}$, and $5 \%$, in cluster $\mathrm{B}$ ) in all the phases in which it can possibly be used (identification, evaluation and monitoring).

In conclusion, a) there are no significant differences in the level of PRM practices' use in the different steps of the PRM process; b) the proportion of cases in clusters B and $\mathrm{C}$ is high $(67 \%$ of total cases), therefore the knowledge about and the implementation of a considerable number/type of PRM practices are still limited; c) patterns across the set of PRM practices indicate that risk practices related with targets (either in the identification or the monitoring phases) are the most used and known, independently of the cluster, followed by the PRM practices related with planning, communication and information record. The least used are those related with tools and techniques, with the exception of "CPM, CPA, PERT" and "KPIs library". More investment in training related with tools and techniques is needed in order to enlarge the set of practices known and used by practitioners.

Table 5. Comparison of clusters in terms of PRM practices' use

Regarding the control variable region, the clusters formed for each region are also three, with similar characteristics, but there are differences in terms of the proportion of cases in each cluster (Table 6). The regions with the higher levels of practices' usage are Europe, North America, and the Middle East; those with lower 
levels are the Middle East, and Africa. It seems that, in the Middle East, there have been simultaneously projects with a very high use of PRM practices and other projects in the lower end of PRM practices' use.

Table 6. Comparison of clusters proportions for the regions

In terms of the context variables, the respondents based their answers on complex projects, essentially measured by "project duration" and "team size", or successful projects. In terms of project complexity, it is difficult to differentiate the clusters (see Table 7), since only cluster A is associated with slightly more complex projects. As expected, higher organizational PRM maturity is associated with higher levels of PRM practices' use.

Table 7. Clusters description

\subsection{Organizational PRM maturity and practices (RQ2)}

CCA was used to quantify the correlation between the set of items that measure the construct organizational PRM maturity and the set of factors that represent the PRM practices' use. The coefficients of the variables for the first canonical function are presented in Table 8 . The higher weights (the magnitude of the weights represents their relative contribution to the variate) are highlighted in bold for both the dependent and the independent canonical variates.

In the function with the highest canonical correlation $\mathrm{RC}^{2}(0.55)$, the most relevant variables of the dependent canonical variate are "information record", "tools 
and techniques", and "cost / time targets", and for the independent canonical variate are "awareness of risk management importance", and "leadership". Since the coefficients of both variates have the same sign, the variables are all positively correlated. Therefore, as expected, it is possible to confirm that organizational PRM maturity influences the set of practices available, which is in line with the results of Golini et al. (2015) and Cagliano et al. (2015).

Table 8. Canonical coefficients for the $1^{\text {st }}$ canonical function

To answer the second research question $(R Q 2)$ that concerns the organizational attributes that influences the practices, Table 9 presents the results of a Regression Analysis relating the influence of organizational PRM maturity on the use of PRM practices using the previous canonical correlation. With the exception of "leadership" (that is not correlated with the identification phase), all organizational PRM maturity items are correlated with all the PRM process steps.

A better "assimilation of risk management concept" $(+1)$ induces an average increase in the use of the "information record" (0.128), "tools and techniques" (evaluation phase) (0.152), "planning actions" (0.100), "tools and techniques" (monitoring phase) (0.113), and "communication" $(0.085)$. Two factors of the PRM practices' use construct are influenced by all the maturity variables: "planning actions" and "communication". The use of "information record" to identify risks is only influenced by the "assimilation of risk management concept". Therefore, it seems that, if the organizations expand the risk management idea, the information record will be more used. In the previous section, it was noted that the "tools and techniques" practices were the least used. Based on the results now obtained, we expect that the use of this type of practices will increase if "risk management capabilities" (0.179), and 
"assimilation of risk management concept" $(0.152)$ are improved. Looking at another key set of practices identified in the previous subsection, "control by goals", it can be observed that it is not correlated with risk specific capabilities; instead, it is mainly influenced by "leadership" (0.156).

Cagliano et al. (2015) had already identified that the higher the maturity towards risk management, the more common the use of quantitative techniques.

Table 9. Regression analysis of the influence of organizational PRM maturity on practices' use

Table 10 shows the effect of organizational PRM maturity moderated by project complexity on practices' usage. To run this moderator analysis using multiple regression, we previously verified the assumptions of linearity, homoscedasticity error independence and normality. The moderating effect exists, although it only induces a slight variation in the Adjusted R square. All the models explain around $28 \%$ to $45 \%$ of the variance in the practices' use. We conclude that the relation between organizational PRM maturity and practices' use is moderated by the complexity of the project. In presence of more complex projects, the use of practices increases slightly, which is in line with the results obtained by Papke-Shields et al. (2010).

Table 10. Adjusted R square between the dependent factor and the predictor

\subsection{Organizational PRM maturity and project performance (RQ3)}

Like Torres (2014) in his literature survey, our analysis concludes that higher organizational maturity leads to better performance. The attributes of organizational 
maturity that contribute the most to enhancing project performance according to our regression model (that explains around $32 \%$ of the variance in project performance; $\mathrm{R}$ square of 0.317 ) are: attitude towards risk, leadership, and management of project knowledge.

\section{Project performance $=-1.475+0.19$ Attitude +0.161 Leadership +0.123 Knowledge}

In Table 11, the regression models considering the items used to measure performance as dependent variables and the items used to measure organizational PRM maturity as independent variables are presented. It seems that, for each attribute of performance, increasing specific organizational PRM maturity items improves performance. Leadership, management of project knowledge, and attitude towards risk appear as indispensable attributes of a PRM mature organization.

\section{Table 11. Regression models}

\section{Conclusions}

This study contributes to a better understanding of PRM practices' use in the six phases of the PRM process, having identified areas for improvement. In general, practices related to information register and information analysis are more used than "tools and techniques". Therefore, according to our data, organizations and professionals should improve their PRM knowledge in this set of practices. For a significant proportion of the project managers surveyed, many of the practices in this category are almost unknown. Probably, because they demand technical training. There are differences in the use of PRM practices related with the world region, with Africa and South America being the regions where this use is lower.

Additionally, this research provides some valuable understanding about the 
relation between organisational PRM maturity and the use of PRM practices moderated by project complexity and adds important empirical information concerning the most important attributes of this relation for each step of the PRM process. More mature organizations use practices more frequently. In the presence of complex projects, more practices are used. The obtained empirical data helps to confirm some hypotheses: a) organizational PRM maturity influences the practices' usage (Golini et al., 2015), b) moderated by project complexity (Papke-Shields et al., 2010), and c) organizational PRM maturity influences the project performance (Yazici 2009; Torres 2014).

In terms of practical implications, project managers can compare their organizations with the determined clusters and identify possible improvement actions to increase the PRM maturity of those organizations. Also, some guidelines about PRM areas lacking training are provided.

In the future, it would be interesting to study different projects (with different complexity levels) developed by the same organization (i.e. considering a given PRM maturity) to verify if there are significant differences in the PRM practices used and in the projects performance.

\section{References}

ANDERSEN, E. S. \& JESSEN, S. A. 2003. Project maturity in organisations. International Journal of Project Management, 21, 457-461.

ARCHER, N. P. \& GHASEMZADEH, F. 1999. An integrated framework for project portfolio selection. International Journal of Project Management, 17, 207-216.

BACCARINI, D. 1996. The concept of project complexity - a review. International Journal of Project Management, 14, 201-204.

BACKLUND, F., CHRONÉER, D. \& SUNDQVIST, E. 2014. Project Management Maturity Models - A Critical Review. Procedia - Social and Behavioral Sciences, $119,837-846$.

BADEWI, A. 2016. The impact of project management (PM) and benefits management $(\mathrm{BM})$ practices on project success: Towards developing a project 
benefits governance framework. International Journal of Project Management, 34, 761-778.

BESNER, C. \& HOBBS, B. 2013. Contextualized Project Management Practice: A Cluster Analysis of Practices and Best Practices. Project Management Journal, 44, 17-34.

BOSCH-REKVELDT, M., JONGKIND, Y., MOOI, H., BAKKER, H. \& VERBRAECK, A. 2011. Grasping project complexity in large engineering projects: The TOE (Technical, Organizational and Environmental) framework. International Journal of Project Management, 29, 728-739.

BROOKES, N., BUTLER, M., DEY, P. \& CLARK, R. 2014. The use of maturity models in improving project management performance. International Journal of Managing Projects in Business, 7, 231-246.

BRYMAN, A. \& BELL, E. 2015. Business research methods, Oxford University Press, USA.

CAGLIANO, A. C., GRIMALDI, S. \& RAFELE, C. 2015. Choosing project risk management techniques. A theoretical framework. Journal of Risk Research, 18, 232248.

CARBONE, T. A. \& TIPPETT, D. D. 2004. Project Risk Management Using the Project Risk FMEA. Engineering Management Journal, 16, 28-35.

CARLSON, K. D. \& HERDMAN, A. O. 2010. Understanding the Impact of Convergent Validity on Research Results. Organizational Research Methods, 15, 1732.

CARVALHO, M. M. D. \& RABECHINI JUNIOR, R. 2015. Impact of risk management on project performance: the importance of soft skills. International Journal of Production Research, 53, 321-340.

DEL CAÑO, A. \& DE LA CRUZ, M. 2002. Integrated Methodology for Project Risk Management. Journal of Construction Engineering and Management, 128, 473-485.

FORTUNE, J. \& WHITE, D. 2006. Framing of project critical success factors by a systems model. International Journal of Project Management, 24, 53-65.

FORTUNE, J., WHITE, D., JUGDEV, K. \& WALKER, D. 2011. Looking again at current practice in project management. International Journal of Managing Projects in Business, 4, 553-572.

GAREIS, R. \& HUEMANN, M. 2000. Project management competences in the project-oriented organisation. In: TURNER, J. R. \& SINISTER, S. J. (eds.) Gower Handbook of Project Management. 3rd ed. Aldershot: Gower.

GERALDI, J., MAYLOR, H. \& WILLIAMS, T. 2011. Now, let's make it really complex (complicated): A systematic review of the complexities of projects. International Journal of Operations \& Production Management, 31, 966-990. 
GOLINI, R., KALCHSCHMIDT, M. \& LANDONI, P. 2015. Adoption of project management practices: The impact on international development projects of nongovernmental organizations. International Journal of Project Management, 33, 650663.

HAIR, J. F., JR., BLACK, W. C., BABIN, B. J. \& ANDERSON, R. E. 2014. Multivariate Data Analysis, Harlow, Essex, Pearson Education Limited.

HILLSON, D. A. 1997. Towards a risk maturity model. The International Journal of Project and Business Risk Management, 1, 35-45.

HILLSON, D. A. 2003. Using a Risk Breakdown Structure in project management. Journal of Facilities Management, 2, 85-97.

HSIEH, H. F. \& SHANNON, S. E. 2005. Three approaches to qualitative content analysis. Qualitative Health Research, 15, 1277-88.

IBBS, C. W. \& KWAK, Y. H. 2000. Assessing project management maturity. Project Management Journal, 31, 32-43.

IBBS, C. W., REGINATO, J. M. \& KWAK, Y. H. 2004. Developing Project Management Capability: Benchmarking, Maturity, Modeling, Gap Analyses, and ROI Studies. In: MORRIS, P. W. G. \& PINTO, J. K. (eds.) The Wiley Guide to Project Organization and Project Management Competencies. Hoboken, NJ: Wiley.

JAIN, A. K. 2010. Data clustering: 50 years beyond K-means. Pattern Recognition Letters, 31, 651-666.

JHA, K. N. \& IYER, K. C. 2006. Critical determinants of project coordination. International Journal of Project Management, 24, 314-322.

JIA, G., NI, X., CHEN, Z., HONG, B., CHEN, Y., YANG, F. \& LIN, C. 2013. Measuring the maturity of risk management in large-scale construction projects. Automation in Construction, 34, 56-66.

JUGDEV, K. \& MÜLLER, R. 2005. A retrospective look at our evolving understanding of project success. Project Management Journal, 36, 19-31.

KARDES, I., OZTURK, A., CAVUSGIL, S. T. \& CAVUSGIL, E. 2013. Managing global megaprojects: Complexity and risk management. International Business Review, 22, 905-917.

KERZNER, H. 2001. Project Management - a Systems Approach to Planning, Scheduling, and Controlling, New York, John Wiley \& Sons.

KETCHEN, D. J., JR. \& SHOOK, C. L. 1996. The application of cluster analysis in strategic management research: an analysis and critique. Strategic Management Journal, 17, 441-458.

KUTSCH, E. \& HALL, M. 2009. The rational choice of not applying project risk management in information technology projects. Project Management Journal, 40, $72-81$. 
KWAK, Y. H. \& IBBS, C. W. 2002. Project Management Process Maturity (PM) ${ }^{2}$ Model. Journal of Management in Engineering, 18, 150-155.

LESTER, D. H. 1998. Critical success factors for new product development. Research Technology Management, 41, 36-43.

LING, F. Y. Y., LOW, S. P., WANG, S. Q. \& LIM, H. H. 2009. Key project management practices affecting Singaporean firms' project performance in China. International Journal of Project Management, 27, 59-71.

LU, Y., LUO, L., WANG, H., LE, Y. \& SHI, Q. 2015. Measurement model of project complexity for large-scale projects from task and organization perspective.

International Journal of Project Management, 33, 610-622.

MAXWELL, J. A. 2008. Designing a qualitative study. In: BICKMAN, L. \& ROG, D. J. (eds.) The Sage handbook of applied social research methods. London: Sage.

MILLIGAN, G. 1980. An examination of the effect of six types of error perturbation on fifteen clustering algorithms. Psychometrika, 45, 325-342.

MULLALY, M. 2006. Longitudinal analysis of project management maturity. Project Management Journal, 37, 62--73.

OLECHOWSKI, A., OEHMEN, J., SEERING, W. \& BEN-DAYA, M. 2016. The professionalization of risk management: What role can the ISO 31000 risk management principles play? International Journal of Project Management, 34, 1568-1578.

PAPKE-SHIELDS, K. E., BEISE, C. \& QUAN, J. 2010. Do project managers practice what they preach, and does it matter to project success? International Journal of Project Management, 28, 650-662.

PASIAN, B., SANKARAN, S. \& BOYDELL, S. 2012. Project management maturity: a critical analysis of existing and emergent factors. International Journal of Managing Projects in Business, 5, 146-157.

PINTO, J. K. 2014. Project management, governance, and the normalization of deviance. International Journal of Project Management, 32, 376-387.

PMI 2004. A Guide to the Project Management Body of Knowledge (PMBOK® Guide), Newtown Square, PA, Project Management Institute, Inc.

PMI 2008. Organizational Project Management Maturity Model (OPM3®):

Knowledge Foundation, Newtown Square, PA, Project Management Institute.

PMI 2017. A Guide to the Project Management Body of Knowledge (PMBOK® Guide), Newtown Square, PA, Project Management Institute, Inc.

POPAITOON, S. \& SIENGTHAI, S. 2014. The moderating effect of human resource management practices on the relationship between knowledge absorptive capacity and project performance in project-oriented companies. International Journal of Project Management, 32, 908-920. 
QURESHI, S. M. \& KANG, C. 2015. Analysing the organizational factors of project complexity using structural equation modelling. International Journal of Project Management, 33, 165-176.

RAMASESH, R. V. \& BROWNING, T. R. 2014. A conceptual framework for tackling knowable unknown unknowns in project management. Journal of Operations Management, 32, 190-204.

RAZ, T., SHENHAR, A. J. \& DVIR, D. 2002. Risk management, project success, and technological uncertainty. R\&D Management, 32, 101-109.

SEI 2006. $C M M I \circledR$ for Development, Version 1.2, Pittsburgh, PA, Software Engineering Institute, Carnegie Mellon.

SENESCU, R., ARANDA-MENA, G. \& HAYMAKER, J. 2012. Relationships between Project Complexity and Communication. Journal of Management in Engineering, 29, 183-197.

SHENHAR, A. J., DVIR, D., LEVY, O. \& MALTZ, A. C. 2001. Project Success: A Multidimensional Strategic Concept. Long Range Planning, 34, 699-725.

TORRES, L. 2014. A Contingency View on the Effect of Project Management Maturity on Perceived Performance.

VICENTE-OLIVA, S., MARTÍNEZ-SÁNCHEZ, Á. \& BERGES-MURO, L. 2015. Research and development project management best practices and absorptive capacity: Empirical evidence from Spanish firms. International Journal of Project Management, 33, 1704-1716.

VIDAL, L.-A. \& MARLE, F. 2008. Understanding project complexity: implications on project management. Kybernetes, 37, 1094-1110.

WARD JR., J. H. 1963. Hierarchical grouping to optimize an objective function. Journal of the American Statistical Association, 58, 236-244.

WESTERVELD, E. 2003. The Project Excellence Model®: linking success criteria and critical success factors. International Journal of Project Management, 21, 411418.

WINTER, M., SMITH, C., COOKE-DAVIES, T. \& CICMIL, S. 2006. The importance of 'process' in Rethinking Project Management: The story of a UK Government-funded research network. International Journal of Project Management, $24,650-662$.

YAZICI, H. J. 2009. The role of project management maturity and organizational culture in perceived performance. Project Management Journal, 40, 14--33.

YEO, K. T. \& REN, Y. 2009. Risk management capability maturity model for complex product systems (CoPS) projects. Systems Engineering, 12, 275-294. 
ZOU, P., CHEN, Y. \& CHAN, T. 2010. Understanding and Improving Your Risk Management Capability: Assessment Model for Construction Organizations. Journal of Construction Engineering and Management, 136, 854-863.

ZWIKAEL, O. \& AHN, M. 2011. The Effectiveness of Risk Management: An Analysis of Project Risk Planning Across Industries and Countries. Risk Analysis, 31, 25-37. 
Table 1. PRM practices considered in the questionnaire

\begin{tabular}{|c|c|}
\hline $\begin{array}{l}\text { Step of the } \\
\text { PRM process }\end{array}$ & Risk management practice or technique (Sources) \\
\hline \multirow[t]{19}{*}{$\begin{array}{l}\text { I. Risk } \\
\text { identification }\end{array}$} & $\begin{array}{l}\text { Risk register*. Risk documentation form. Risk management ledger (Papke-Shields. Beise. and } \\
\text { Quan 2010. Kululanga and Kuotcha 2010. Yeo and Ren 2009); }\end{array}$ \\
\hline & $\begin{array}{l}\text { Risk checklist* (Zwikael and Ahn 2011. Zhou. Vasconcelos. and Nunes 2008. Teller and Kock } \\
\text { 2013. PMI 2009); }\end{array}$ \\
\hline & Post project review. Lessons learned. Historical review (PMI 2009. Hillson 2003); \\
\hline & $\begin{array}{l}\text { Periodic risk review* (Papke-Shields. Beise. and Quan 2010. Kululanga and Kuotcha 2010. Yeo } \\
\text { and Ren 2009); }\end{array}$ \\
\hline & $\begin{array}{l}\text { Risk breakdown structure (RBS) (Yeo and Ren 2009. Kululanga and Kuotcha 2010. Dey. Kinch. } \\
\text { and Ogunlana 2007. PMI 2009. Hillson 2003); }\end{array}$ \\
\hline & $\begin{array}{l}\text { Brainstorming (de Bakker. Boonstra. and Wortmann 2010. Goh. Abdul-Rahman. and Abdul } \\
\text { Samad 2012. Hillson 2003); }\end{array}$ \\
\hline & $\begin{array}{l}\text { Critical path method (CPM). Critical path analysis (CPA). Program evaluation and review } \\
\text { technique (PERT) (Papke-Shields. Beise. and Quan 2010. White and Fortune 2002); }\end{array}$ \\
\hline & Time-phased budget plan monitoring* (Papke-Shields. Beise. and Quan 2010); \\
\hline & Project time schedule* (Papke-Shields. Beise. and Quan 2010); \\
\hline & $\begin{array}{l}\text { Interview with experts* (PMI 2009. de Bakker. Boonstra. and Wortmann 2010. Dikmen et al. } 2010 . \\
\text { Papke-Shields. Beise. and Quan 2010. Kululanga and Kuotcha 2010. Hillson 2003); }\end{array}$ \\
\hline & Questionnaires and interviews (PMI 2009. de Bakker. Boonstra. and Wortmann 2010); \\
\hline & Decision analysis (White and Fortune 2002. PMI 2009); \\
\hline & $\begin{array}{l}\text { Delphi method* (PMI 2009. Papke-Shields. Beise. and Quan 2010. de Bakker. Boonstra. and } \\
\text { Wortmann 2010); }\end{array}$ \\
\hline & $\begin{array}{l}\text { Work breakdown structure (WBS) (Papke-Shields. Beise. and Quan 2010. White and Fortune } \\
\text { 2002. PMI 2009); }\end{array}$ \\
\hline & Failure modes and effects analysis (FMEA) (White and Fortune 2002. PMI 2009); \\
\hline & Fault tree analysis. Event tree analysis (PMI 2009. White and Fortune 2002); \\
\hline & Hazard analysis (HAZAN). Hazard and operability studies (HAZOP) (White and Fortune 2002); \\
\hline & Life cycle cost analysis (White and Fortune 2002. Papke-Shields. Beise. and Quan 2010); \\
\hline & Ishikawa Diagram* (Hayashi and Kataoka 2008). \\
\hline \multirow[t]{11}{*}{$\begin{array}{l}\text { II. Risk } \\
\text { evaluation }\end{array}$} & $\begin{array}{l}\text { Risk register. Risk documentation form. Risk management ledger (Papke-Shields. Beise. and Quan } \\
\text { 2010. Kululanga and Kuotcha 2010. Yeo and Ren 2009); }\end{array}$ \\
\hline & $\begin{array}{l}\text { Probability and impact grids. Risk matrix. Risk map (White and Fortune 2002. PMI 2009. Yeo and } \\
\text { Ren 2009. Zhou. Vasconcelos. and Nunes 2008); }\end{array}$ \\
\hline & $\begin{array}{l}\text { Risk breakdown structure (RBS) (Yeo and Ren 2009. Kululanga and Kuotcha 2010. Dey. Kinch. } \\
\text { and Ogunlana 2007. PMI 2009. Hillson 2003); }\end{array}$ \\
\hline & Decision analyzis (White and Fortune 2002. PMI 2009); \\
\hline & $\begin{array}{l}\text { Delphi method* (PMI 2009. Papke-Shields. Beise. and Quan 2010. de Bakker. Boonstra. and } \\
\text { Wortmann 2010); }\end{array}$ \\
\hline & Probability analyzis*. Reliability Analyzis (White and Fortune 2002); \\
\hline & Monte Carlo simulation (White and Fortune 2002. PMI 2009); \\
\hline & Multi-criteria analyzis (PMI 2009. White and Fortune 2002); \\
\hline & CPM. CPA. PERT (Papke-Shields. Beise. and Quan 2010. White and Fortune 2002); \\
\hline & $\begin{array}{l}\text { Strengths-Weaknesses-Opportunities-Threats (SWOT) analyzis* (Hillson 2003. White and } \\
\text { Fortune 2002. PMI 2009); }\end{array}$ \\
\hline & $\begin{array}{l}\text { Analytic Hierarchy Process (AHP) (PMI 2009. Ho. Xu. and Dey 2010. Dikmen et al. 2010); } \\
\text { Cluster analyzis (PMI 2009) }\end{array}$ \\
\hline
\end{tabular}




\begin{tabular}{|c|c|}
\hline \multirow{6}{*}{$\begin{array}{l}\text { III. Planning } \\
\text { actions against } \\
\text { risk }\end{array}$} & $\begin{array}{l}\text { Action plan. Mitigation plan* (Papke-Shields. Beise. and Quan 2010. Gil and Tether 2011. Kwak } \\
\text { and Smith 2009) }\end{array}$ \\
\hline & $\begin{array}{l}\text { Contingency plan (Papke-Shields. Beise. and Quan 2010. PMI 2009. Kululanga and Kuotcha } \\
\text { 2010); }\end{array}$ \\
\hline & Risk owner definition (Yeo and Ren 2009); \\
\hline & SWOT analysis* (Hillson 2003. White and Fortune 2002. PMI 2009); \\
\hline & Design Flexibility (Gil and Tether 2011. White and Fortune 2002); \\
\hline & 5W2H (What. When. Where. Why. Who. How. How Much) analysis*. \\
\hline \multirow[t]{14}{*}{$\begin{array}{l}\text { IV. Risk } \\
\text { monitoring }\end{array}$} & $\begin{array}{l}\text { Periodic risk review* (Papke-Shields. Beise. and Quan 2010. Kululanga and Kuotcha 2010. Yeo } \\
\text { and Ren 2009); }\end{array}$ \\
\hline & $\begin{array}{l}\text { Reported monitoring of project risks. including Risks status reports and Status review meetings } \\
\text { (Papke-Shields. Beise. and Quan 2010. Yeo and Ren 2009); }\end{array}$ \\
\hline & Organizational structure of risk monitoring (Ho. Xu. and Dey 2010); \\
\hline & Project time schedule (Papke-Shields. Beise. and Quan 2010); \\
\hline & Time-phased budget plan monitoring* (Papke-Shields. Beise. and Quan 2010); \\
\hline & CPM. CPA. PERT (Papke-Shields. Beise. and Quan 2010. White and Fortune 2002); \\
\hline & Post project review. Lessons learned. Historical review (PMI 2009. Hillson 2003); \\
\hline & $\begin{array}{l}\text { Earned value management (EVM). Earned value analysis (EVA) (PMI 2009. Hayashi and Kataoka } \\
\text { 2008. Kululanga and Kuotcha 2010) }\end{array}$ \\
\hline & Quality control (Papke-Shields. Beise. and Quan 2010); \\
\hline & Key performance indicators library (KPIs) (PMI 2004); \\
\hline & Customer satisfaction survey (de Bakker. Boonstra. and Wortmann 2010); \\
\hline & S-Curve* (PMI 2004); \\
\hline & Balanced scorecard*; \\
\hline & Milestones planning* (PMI 2004). \\
\hline \multirow{6}{*}{$\begin{array}{l}\text { V. } \\
\text { Communication } \\
\text { and integration }\end{array}$} & Communication practices (PMI 2009. Papke-Shields. Beise. and Quan 2010); \\
\hline & $\begin{array}{l}\text { Reported monitoring of project risks. including Risk status reports and Status review meetings } \\
\text { (Papke-Shields. Beise. and Quan 2010. Yeo and Ren 2009); }\end{array}$ \\
\hline & Integration (social) practices* (Bresnen et al. 2003); \\
\hline & Knowledge management* (PMI 2009. Teller and Kock 2013); \\
\hline & $\begin{array}{l}\text { Training (team building events) (Papke-Shields. Beise. and Quan 2010. White and Fortune } 2002 . \\
\text { PMI 2009); }\end{array}$ \\
\hline & $\begin{array}{l}\text { Engaging stakeholders* (White and Fortune 2002. Papke-Shields. Beise. and Quan 2010. PMI } \\
\text { 2013b). }\end{array}$ \\
\hline \multirow{6}{*}{$\begin{array}{l}\text { VI. } \\
\text { Management } \\
\text { support tasks }\end{array}$} & Periodic project meeting (Teller and Kock 2013. Gil and Tether 2011. White and Fortune 2002); \\
\hline & Benchmarking (Teller and Kock 2013. Luu. Kim. and Huynh 2008); \\
\hline & Prototype. Mock-up (Hayashi and Kataoka 2008); \\
\hline & Document review (lessons learnt reports) (White and Fortune 2002); \\
\hline & $\begin{array}{l}\text { Total quality management (TQM). International Organisation for Standardization (ISO) } \\
\text { standards*. European Foundation for Quality Management (EFQM) excellence model } \\
\text { (Papke-Shields. Beise. and Quan 2010. Kululanga and Kuotcha 2010); }\end{array}$ \\
\hline & Human resources management practices (PMI 2004). \\
\hline
\end{tabular}

* used by PM practitioners interviewed. 
Table 2. Profile of the respondents

\begin{tabular}{cccc}
\hline & Characteristics & Interviewees & $\begin{array}{c}\text { Survey } \\
\text { respondents }\end{array}$ \\
\hline \multirow{3}{*}{ Gender } & Male & $80 \%$ & $84.1 \%$ \\
& Female & $20 \%$ & $13.4 \%$ \\
No answer & 0 & $2.5 \%$ \\
\hline \multirow{4}{*}{ Age } & $>60$ years & $0 \%$ & $6.6 \%$ \\
& 50 to 60 years & $20 \%$ & $21.2 \%$ \\
& 40 to 50 years & $60 \%$ & $29.6 \%$ \\
& 30 to 40 years & $20 \%$ & $30.3 \%$ \\
Formal Education & $<30$ years & $0 \%$ & $6.1 \%$ \\
& No answer & $0 \%$ & $6.2 \%$ \\
\hline Post-Doctoral Studies & $0 \%$ & $1.4 \%$ \\
& Doctoral Studies & $40 \%$ & $6.4 \%$ \\
& Master Studies & $60 \%$ & $47.5 \%$ \\
& Post-graduation & $0 \%$ & $13.4 \%$ \\
Specialization & $0 \%$ & $7.3 \%$ \\
& Bachelor & $0 \%$ & $21.3 \%$ \\
& 12 th level (High School) & $0 \%$ & $2.4 \%$ \\
No answer & $0 \%$ & $0.3 \%$ \\
\hline & $>10$ years & $40 \%$ & $54.9 \%$ \\
& $>5$ years and $\leq 10$ years & $40 \%$ & $29.7 \%$ \\
& 2 years and $\leq 5$ years & $20 \%$ & $12.8 \%$ \\
& $\leq 2$ years & $0 \%$ & $1.7 \%$ \\
& No answer & $0 \%$ & $0.9 \%$ \\
\hline
\end{tabular}


Table 3. Cronbach's alpha

\begin{tabular}{lcc}
\hline Sections & \# Items & Cronbach's alpha \\
\hline Complexity & 10 & 0.766 \\
\hline Performance & 6 & 0.845 \\
\hline Maturity & 6 & 0.871 \\
\hline Best practices related to: & & \\
$\quad$ Risk identification & 19 & 0.926 \\
Risk evaluation & 13 & 0.923 \\
Planning actions against risk & 9 & 0.883 \\
Risk monitoring & 14 & 0.921 \\
Communication and inclusion & 6 & 0.923 \\
Management support tasks & 7 & 0.860 \\
\hline
\end{tabular}


Table 4. Pearson inter-factor correlation coefficients

\begin{tabular}{|c|c|c|c|c|c|c|c|c|c|c|c|c|c|c|}
\hline & 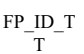 & ${ }_{\overrightarrow{\mathrm{R}}}^{\mathrm{FP}} \mathrm{ID} \_\mathrm{I}$ & 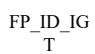 & $\mathrm{FP}_{-} \mathrm{ID}_{-}$ & 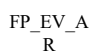 & $\mathrm{FP}_{-\mathrm{T}}^{\mathrm{EV}} \mathrm{TV}_{-} \mathrm{T}$ & FP_PL & $\underset{\mathrm{G}}{\mathrm{FP}-\mathrm{CT} \_\mathrm{C}}$ & $\begin{array}{l}\mathrm{FP}_{-} \mathrm{CT} \text { T } \mathrm{T} \\
\mathrm{T}\end{array}$ & $\mathrm{FP}_{\mathrm{M}}^{\mathrm{C}}$ & FP_SP & FOM & FPC & $\begin{array}{c}\text { FP } \\
\text { P }\end{array}$ \\
\hline FP_ID_TT & 1 & & & & & & & & & & & & & \\
\hline FP_ID_IR & $\approx 0$ & 1 & & & & & & & & & & & & \\
\hline$\underset{\text { T }}{\text { FP_ID_IG }}$ & $\approx 0$ & $\approx 0$ & 1 & & & & & & & & & & & \\
\hline FP_ID_T & $\approx 0$ & $\approx 0$ & $\approx 0$ & 1 & & & & & & & & & & \\
\hline$\underset{\mathrm{R}}{\mathrm{FP}}$ & $.668^{* *}$ & $.322^{* *}$ & $.368^{* * *}$ & $.086^{*}$ & 1 & & & & & & & & & \\
\hline FP_EV_TT & $.143^{* *}$ & $.763^{* *}$ & $.243^{* *}$ & $.190^{* *}$ & $\approx 0$ & 1 & & & & & & & & \\
\hline FP_PL & $.324^{* *}$ & $.545^{* *}$ & $.438^{* *}$ & $.302^{* *}$ & $.444^{* *}$ & $.678^{* *}$ & 1 & & & & & & & \\
\hline$\underset{\mathrm{G}_{\mathrm{G}}}{\mathrm{FP} \mathrm{CT}_{-} \mathrm{C}}$ & .052 & $.535^{* *}$ & $.295^{* *}$ & $.506^{* *}$ & $.099^{*}$ & $.645^{* *}$ & $.738^{*}$ & 1 & & & & & & \\
\hline FP_CT_TT & $.616^{* *}$ & $.145^{* *}$ & $.281^{* *}$ & $.097^{*}$ & $.685^{* *}$ & $.266^{* *}$ & $.454^{*}$ & $\approx 0$ & 1 & & & & & \\
\hline FP_CM & $.182^{* *}$ & $.488^{* *}$ & $.519^{* *}$ & $.220^{* *}$ & $.347^{* *}$ & $.585^{* *}$ & $.780^{*}$ & $.667^{* *}$ & $.372^{* *}$ & 1 & & & & \\
\hline FP_SP & $.431^{* *}$ & $.434^{* *}$ & $.473^{* * *}$ & $.219^{* *}$ & $.535^{* *}$ & $.561^{* *}$ & $\begin{array}{l}.794^{*} \\
*\end{array}$ & $.592^{* *}$ & $.542^{* *}$ & $.765^{* *}$ & 1 & & & \\
\hline FOM & $.270^{* *}$ & $.522^{* *}$ & $.290^{* * *}$ & $.274^{* *}$ & $.322^{* * *}$ & $.591^{* *}$ & $.662^{*}$ & $.572^{* *}$ & $.335^{* *}$ & $.611^{* *}$ & $.601^{*}$ & 1 & & \\
\hline FPC & $.107^{* * *}$ & $.161^{* *}$ & 0.018 & $.137^{* *}$ & $.079^{*}$ & $.226^{* *}$ & $.218^{*}$ & $.208^{* *}$ & $.127^{* * *}$ & $.155^{* *}$ & $.169^{*}$ & $.235^{*}$ & 1 & \\
\hline FPP & $.125^{* *}$ & $.226^{* *}$ & $.156^{* *}$ & $.120^{* *}$ & $.156^{* *}$ & $.241^{* *}$ & $.352^{*}$ & $.317^{* *}$ & $.159^{* * *}$ & $.308^{* *}$ & $.307^{*}$ & $.433^{*}$ & $\begin{array}{c}.04 \\
6 \\
\end{array}$ & 1 \\
\hline
\end{tabular}

Notes: FP_ID_TT: Fpractices_identification_tools and techniques; FP_ID_IR: Fpractices_identification_information record;

FP ID IGT: Fpractices identification Information gathering tools; FP ID T:Fpractices identification targets;

FP_EV_AR: Fpractices_evaluation_analysis of risk; FP_EV_TT: Fpractices_evaluation_tools and techniques;

FP_PL: Fpractices_planning; FP_CT_CG: Fpractices_control_control by goals; FP_CT_TT: Fpractices_control_tools and techniques;

FP CM: Fpractices communication; FP SP: Fpractices support;

FOM: Forganizational_maturity; FPC: Fproject_complexity; FPP: Fproject_performance.

** Correlation is significant at the 0.01 level (2-tailed). 
Table 5. Comparison of clusters in terms of PRM practices use

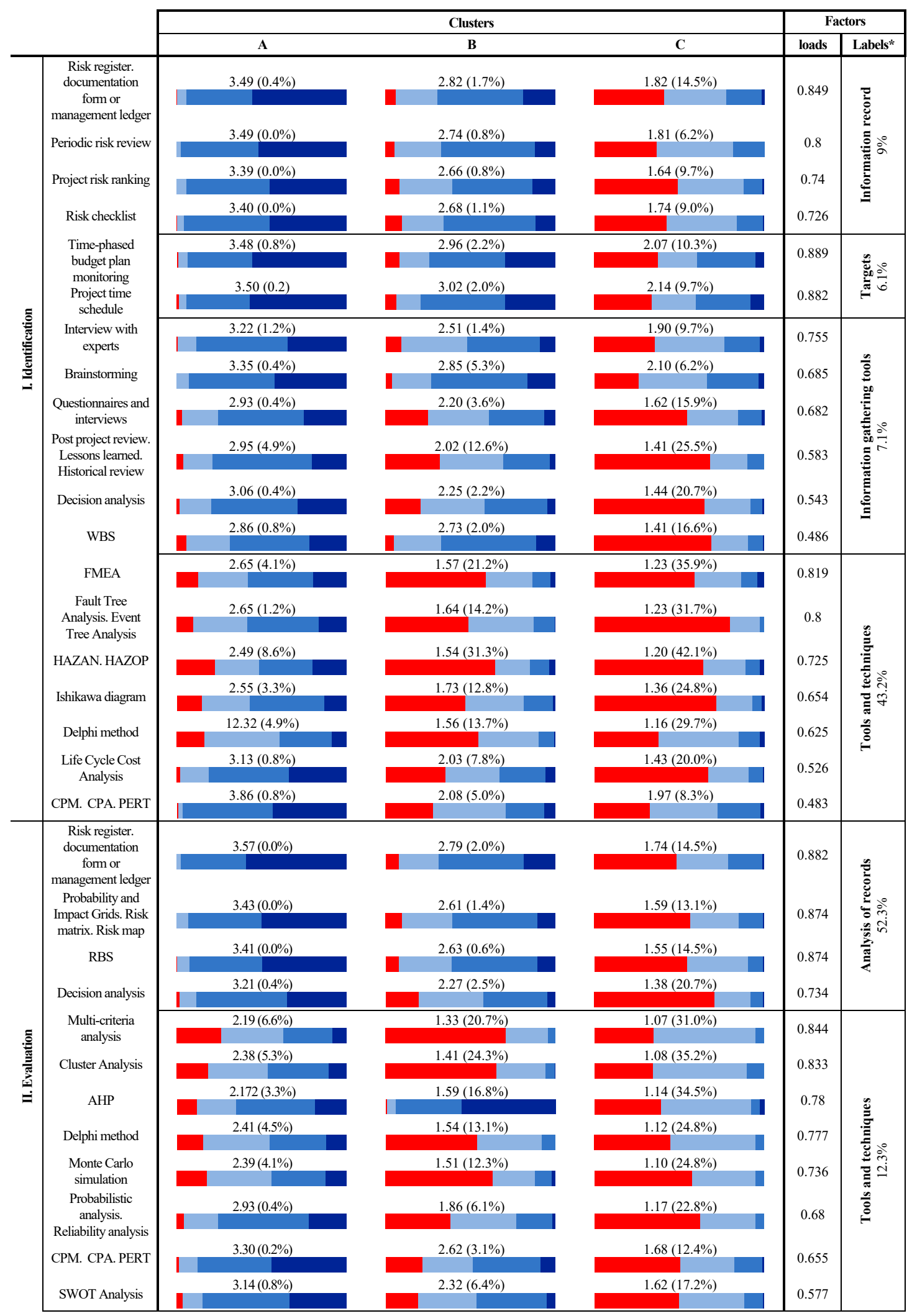




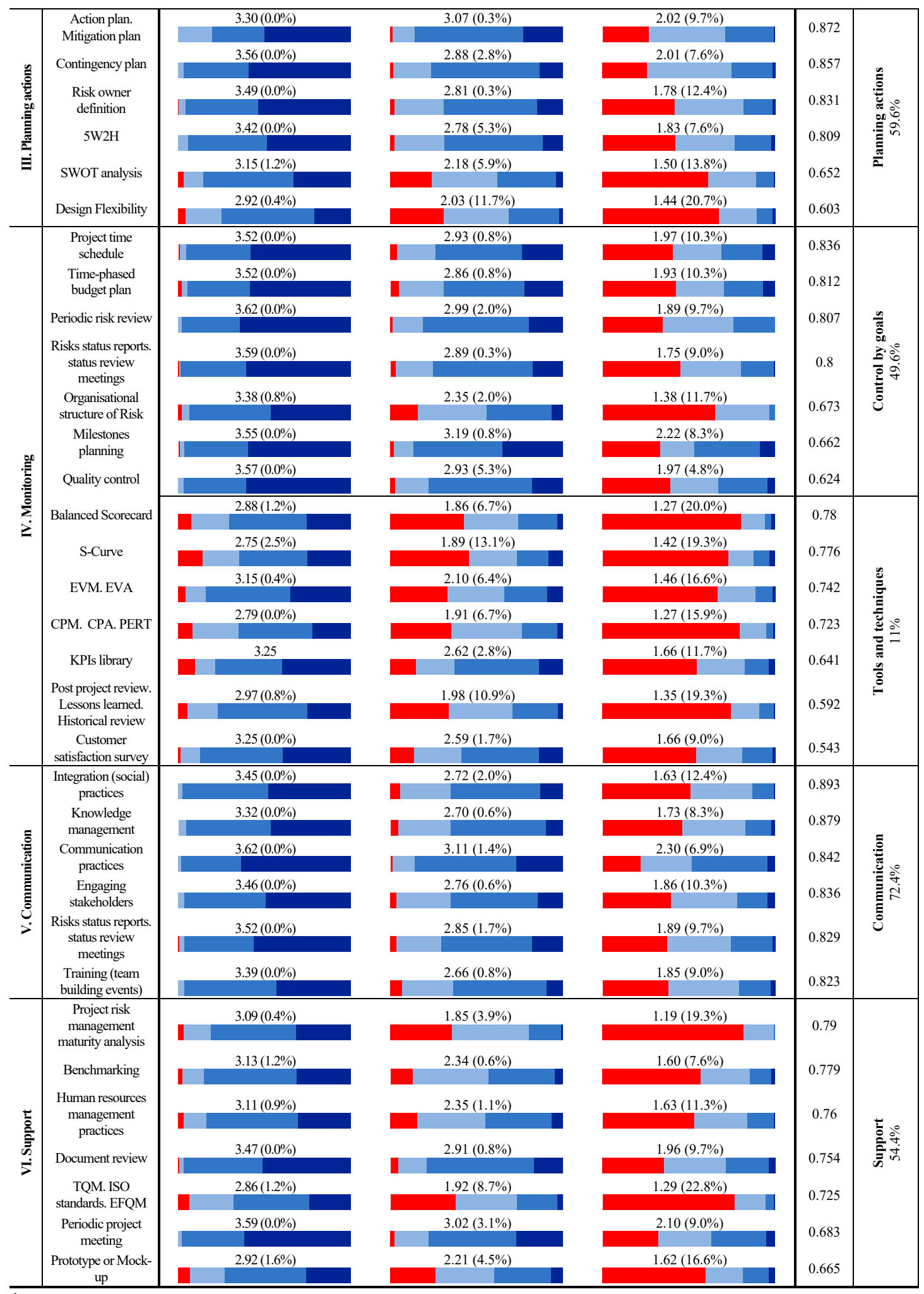

* The $\%$ of variance explained by the factor is also presented; $(0.0 \%)$ in parenthesis the percentage of cases that unknown the practice. Legend: Not used $\longrightarrow$ Used very frequently. 
Table 6. Comparison of clusters proportions for the regions

\begin{tabular}{|c|c|c|c|}
\hline \multirow[b]{2}{*}{ Regions } & Cluster A & Cluster B & Cluster C \\
\hline & $\begin{array}{c}\text { higher level of PRM } \\
\text { practices' use }\end{array}$ & $\begin{array}{c}\text { average level of PRM } \\
\text { practices' use }\end{array}$ & $\begin{array}{c}\text { low level of PRM } \\
\text { practices' use }\end{array}$ \\
\hline World & $33 \%$ & $48 \%$ & $19 \%$ \\
\hline Africa & $19 \%$ & $50 \%$ & $31 \%$ \\
\hline Asia & $36 \%$ & $44 \%$ & $20 \%$ \\
\hline Europe & $44 \%$ & $44 \%$ & $12 \%$ \\
\hline North America & $42 \%$ & $41 \%$ & $17 \%$ \\
\hline South America & $26 \%$ & $51 \%$ & $23 \%$ \\
\hline Midlle East & $43 \%$ & $7 \%$ & $50 \%$ \\
\hline Oceania & $36 \%$ & $45 \%$ & $18 \%$ \\
\hline
\end{tabular}


Table 7. Clusters description

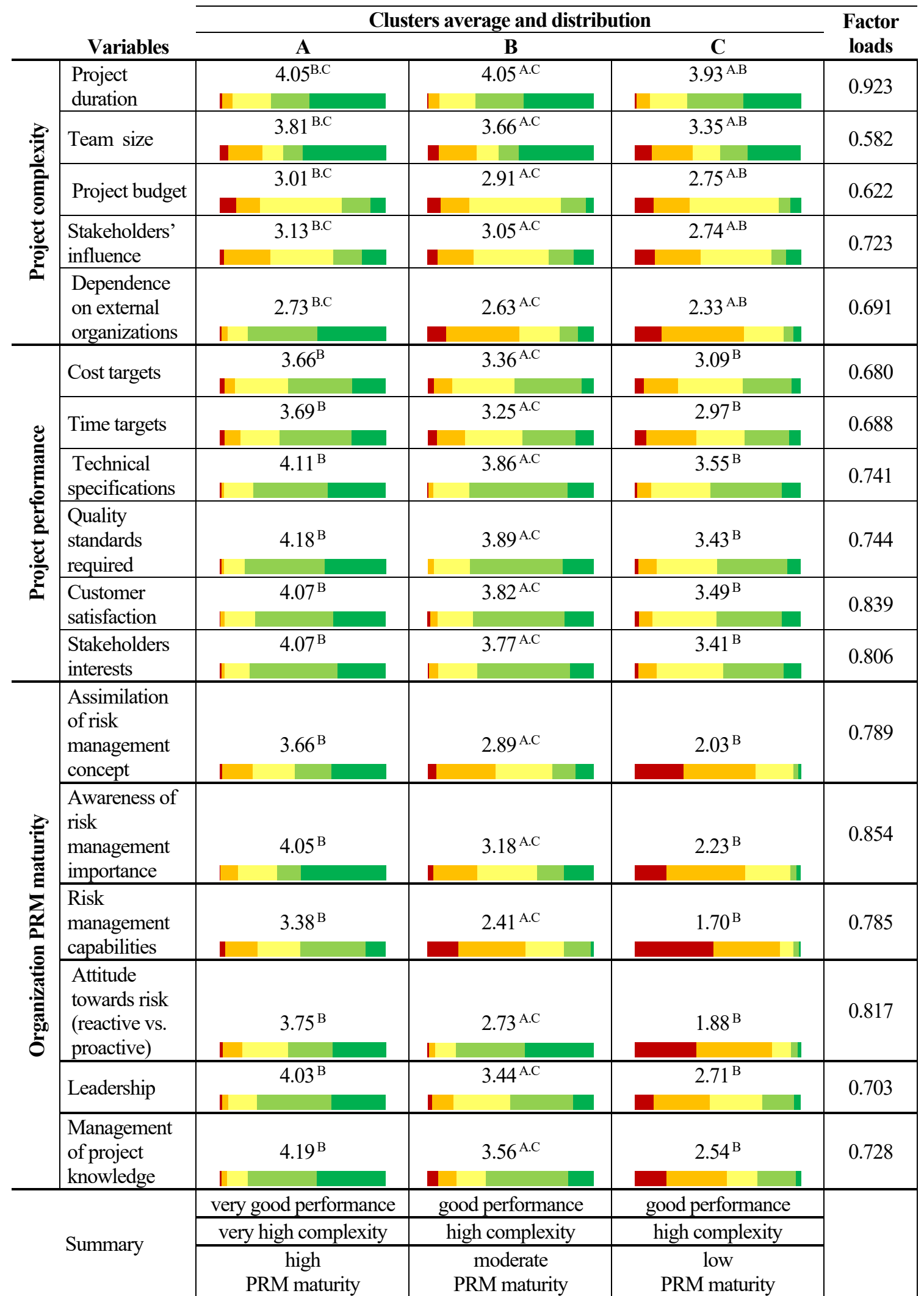

Legend: A: According to Tamhane's T2 test: the average of the cluster cannot be considered different from that of cluster A ( $p$ value $>0.05)$; $B$ : the average of the cluster cannot be considered different from that of cluster B; etc.;

$1 \longleftrightarrow \rightarrow 5$ 
Table 8 - Canonical coefficients for the $1^{\text {st }}$ canonical function

\begin{tabular}{|c|c|}
\hline Variate/Variables & Canonical coefficients \\
\hline $\mathrm{RC}^{2}$ & 0.55 \\
\hline dependent variables & PRM Practices \\
\hline Tools and techniques & -0.249 \\
\hline Information record & -0.486 \\
\hline Information gathering tools & -0.166 \\
\hline Cost / time targets & -0.223 \\
\hline Analysis of records of information & -0.147 \\
\hline Tools and techniques & -0.114 \\
\hline Planning actions & -0.173 \\
\hline Control by goals & -0.011 \\
\hline Tools and techniques & -0.088 \\
\hline Support tasks & -0.282 \\
\hline Communication & 0.094 \\
\hline independet variables & organizational PRM maturity \\
\hline $\begin{array}{l}\text { Assimilation of risk management } \\
\text { concept }\end{array}$ & -0.181 \\
\hline $\begin{array}{c}\text { Awareness of risk management } \\
\text { importance }\end{array}$ & -0.237 \\
\hline Risk management capabilities & -0.147 \\
\hline $\begin{array}{l}\text { Attitude towards risk (reactive vs. } \\
\text { proactive) }\end{array}$ & -0.185 \\
\hline Leadership & -0.208 \\
\hline $\begin{array}{l}\text { Management of project } \\
\text { knowledge }\end{array}$ & -0.137 \\
\hline $\begin{array}{c}1^{\text {st }} \text { canonical function explained } \\
\text { variance } \\
\text { of the correlation }\end{array}$ & $86 \%$ \\
\hline
\end{tabular}


Table 9. Regression analysis of the influence of organizational PRM maturity on practices' use

\begin{tabular}{|c|c|c|c|c|c|c|}
\hline $\begin{array}{l}\text { Steps of the } \\
\text { PRM process }\end{array}$ & PRM practices & $\begin{array}{l}\text { Assimilation } \\
\text { of risk } \\
\text { management } \\
\text { concept }\end{array}$ & $\begin{array}{c}\text { Risk } \\
\text { management } \\
\text { capabilities }\end{array}$ & $\begin{array}{c}\text { Attitude } \\
\text { towards risk } \\
\text { (reactive vs. } \\
\text { proactive) } \\
\end{array}$ & Leadership & $\begin{array}{c}\text { Management } \\
\text { of project } \\
\text { knowledge }\end{array}$ \\
\hline \multirow{3}{*}{ Identification } & $\begin{array}{l}\text { Tools and } \\
\text { techniques }\end{array}$ & & 0.179 & & & \\
\hline & $\begin{array}{c}\text { Information } \\
\text { record }\end{array}$ & 0.128 & & & & \\
\hline & $\begin{array}{l}\text { Information } \\
\text { gathering tools }\end{array}$ & & & 0.103 & & 0.181 \\
\hline \multirow[t]{2}{*}{ Evaluation } & $\begin{array}{l}\text { Analysis of } \\
\text { records of } \\
\text { information }\end{array}$ & & 0.19 & 0.159 & & \\
\hline & $\begin{array}{l}\text { Tools and } \\
\text { techniques }\end{array}$ & 0.152 & & & 0.1 & 0.091 \\
\hline Planning & Planning actions & 0.1 & 0.096 & 0.112 & 0.169 & 0.144 \\
\hline \multirow[b]{2}{*}{ Monitoring } & Control by goals & & & & 0.156 & 0.085 \\
\hline & $\begin{array}{l}\text { Tools and } \\
\text { techniques }\end{array}$ & 0.113 & 0.138 & 0.139 & & \\
\hline \multicolumn{2}{|c|}{ Communication } & 0.085 & 0.153 & 0.15 & 0.132 & 0.112 \\
\hline \multicolumn{2}{|c|}{ Support } & & & 0.166 & 0.132 & 0.163 \\
\hline
\end{tabular}

Note: Only the statistically significant coefficients are presented (p-value $<0.05$ ); 
Table 10. Adjusted R square between the dependent factor and the predictor

\begin{tabular}{|c|c|c|c|c|c|}
\hline \multirow{2}{*}{$\begin{array}{c}\text { steps of } \\
\text { PRM } \\
\text { process }\end{array}$} & PRM & \multicolumn{2}{|c|}{ Without moderator } & \multicolumn{2}{c|}{ With project complexity as moderator } \\
\cline { 3 - 6 } practices & $\begin{array}{c}\text { Adjusted } \\
\text { R square }\end{array}$ & Coefficients & $\begin{array}{c}\text { Adjusted } \\
\text { R square }\end{array}$ & Coefficients \\
\hline Identification & $\begin{array}{c}\text { Information } \\
\text { record }\end{array}$ & 0.273 & $0.522 \mathrm{~m}$ & 0.273 & $-0.002+0.520 \mathrm{~m}+0.035 \mathrm{~m}^{*} \mathrm{c}$ \\
\hline Evaluation & $\begin{array}{c}\text { Tools and } \\
\text { techniques }\end{array}$ & 0.349 & $0.591 \mathrm{~m}$ & 0.36 & $-0.002+0.588 \mathrm{~m}+0.039 \mathrm{~m}^{*} \mathrm{c}$ \\
\hline Planning & $\begin{array}{c}\text { Planning } \\
\text { actions }\end{array}$ & 0.439 & $0.662 \mathrm{~m}$ & 0.443 & $-0.004+0.658 \mathrm{~m}+0.057 \mathrm{~m}^{*} \mathrm{c}$ \\
\hline Monitoring & $\begin{array}{c}\text { Control by } \\
\text { goals }\end{array}$ & 0.327 & $0.572 \mathrm{~m}$ & 0.338 & $0.016+0.56 \mathrm{~m}+0.81 \mathrm{c}+0.72 \mathrm{~m}^{*} \mathrm{c}$ \\
\hline \multicolumn{2}{|c|}{ Communication } & 0.374 & $0.611 \mathrm{~m}$ & 0.386 & $\begin{array}{r}-0.003+0.613 \mathrm{~m}- \\
0.097 \mathrm{c}+0.55 \mathrm{~m} * \mathrm{c}\end{array}$ \\
\hline \multicolumn{2}{|c|}{ Support } & 0.361 & $0.601 \mathrm{~m}$ & 0.367 & $-0.005+0.599 \mathrm{~m}+0.022 \mathrm{~m}^{*} \mathrm{c}$ \\
\hline
\end{tabular}

Note: m-organizational PRM maturity; c-project complexity. $m^{*} c$-interaction term 
Table 11. Regression models

\begin{tabular}{|c|c|c|}
\hline & $\begin{array}{c}\mathrm{R} \\
\text { Squar } \\
\mathrm{e}\end{array}$ & Model \\
\hline $\begin{array}{c}\text { Time targets } \\
\text { Technical }\end{array}$ & 0.223 & $2.248+0.115$ Leadership +0.239 Attitude \\
\hline $\begin{array}{l}\text { specification } \\
\mathrm{s}\end{array}$ & 0.223 & $2.898+0.118$ Leadership +0.108 Knowledge +0.075 Capabilities \\
\hline $\begin{array}{c}\text { Quality } \\
\text { standards } \\
\text { required }\end{array}$ & 0.238 & $\begin{array}{l}2.841+0.096 \text { Leadership }+0.087 \text { Attitude }+0.063 \text { Knowledge }+0.072 \text { Awarenes } \\
s\end{array}$ \\
\hline $\begin{array}{l}\text { Customer } \\
\text { satisfaction }\end{array}$ & 0.227 & $2.794+0.127$ leadership +0.114 Attitude +0.076 Knowledge \\
\hline $\begin{array}{l}\text { Stakeholders } \\
\text { interests }\end{array}$ & 0.246 & $2.707+0.143$ Leadership +0.127 Attitude +0.064 Knowledge \\
\hline
\end{tabular}

